\title{
Evaluation of Novel 4-Thiazolidinone-Based Derivatives as Possible Cytoprotective Agents against Stress Model in Rats
}

\author{
Iryna Ilkiv $^{1 *}$, Roman Lesyk ${ }^{2}$, Olexandr Sklyarov ${ }^{1}$ \\ ${ }^{1}$ Department of Biochemistry, Danylo Halytsky Lviv National Medical University, Lviv 79010, Ukraine. \\ ${ }^{2}$ Department of Pharmaceutical, Organic and Bioorganic Chemistry, Danylo Halytsky Lviv National Medical University, Lviv 79010, Ukraine.
}

\begin{tabular}{|c|c|}
\hline ARTICLE INFO & ABSTRACT \\
\hline Article history: & \multirow{9}{*}{$\begin{array}{l}\text { Multiple factors, such as increased intestinal barrier permeability, upregulation of iNOS/NO expression and } \\
\text { decreased } \mathrm{H}_{2} \mathrm{~S} \text { synthesis are involved in the pathogenesis of inflammation. The purpose of this investigation was } \\
\text { to explore the role of } 4 \text {-thiazolidinone-based derivatives as a novel donors of } \mathrm{H}_{2} \mathrm{~S} \text { in promoting the resolution of } \\
\text { inflammation in small intestine. In the present study, we investigated the effect of novel 4-thiazolidinone } \\
\text { derivatives (compounds Les-5054 and Les-5055) on various intestinal events occurring in association with } \\
\text { stress-induced gastrointestinal damage. It was observed an intensification of lipid peroxidation, } \\
\text { myeloperoxidase activity, accompanied by increase of iNOS activity, NO production and decrease of } \mathrm{H}_{2} \mathrm{~S} \\
\text { content in rats with water-immersion stress group. In animals treated with compounds Les-5054 and Les-5055 } \\
\text { the reduction of the activity of iNOS, myeloperoxidase, intensity of lipid peroxidation and increased generation } \\
\text { of } \mathrm{H}_{2} \mathrm{~S} \text { were revealed. } 4 \text {-thiazolidinone-based derivatives increased small intestine mucosal activity of anti- } \\
\text { oxidative enzymes SOD and catalase in rats subjected to stress. The compound Les-5054 showed significant } \\
\text { efficacious effect and antioxidant properties compared to compound Les-5055. }\end{array}$} \\
\hline Received on: 13/06/2016 & \\
\hline Revised on: 17/07/2016 & \\
\hline Accepted on: 18/09/2016 & \\
\hline Available online: 31/01/2017 & \\
\hline Key words: & \\
\hline Hydrogen sulfide, small & \\
\hline intestine, water-immersion & \\
\hline stress, 4-thiazolidinones. & \\
\hline
\end{tabular}

\section{INTRODUCTION}

The prevention of gastrointestinal mucosa injury caused by different endogenous (acid, digestive enzymes, bile) and exogenous (stress, NSAIDs) agents is depending on mucosal defense (Wallace, 2010). For instance, stress affects the integrity of the intestinal barrier and increases it permeability (Lambert, 2009), reduces mucosal blood flow due to catecholamines driven vasoconstriction, leading to hypoxia and nitroso-oxidative processes (Fomenko et al., 2015). In addition, Lou et al. (2008) demonstrated the influence of stress into generation of hydrogen sulfide $\left(\mathrm{H}_{2} \mathrm{~S}\right)$ in gastrointestinal mucosa. Thus, the experimental data demonstrates that $\mathrm{H}_{2} \mathrm{~S}$ can exert protective actions against injury induced by various factors (Aboubakr et al., 2013; Chan and Wallace, 2013; Zayachkivska et al., 2014). The small intestine is a key target of such gaseous mediators as nitric oxide (NO) and $\mathrm{H}_{2} \mathrm{~S}$. Various small intestine pathological conditions

* Corresponding Author

E-mail:ira9ilkiv@gmail.com including ulcers, malignancies, and enteropathies arise in part from decreasing synthesis of $\mathrm{H}_{2} \mathrm{~S}$ (Magierowski et al., 2015). Understanding the signaling events initiated by gaseous mediators as well as the physiological response to such processes is key to furthering our understanding of $\mathrm{H}_{2} \mathrm{~S}$-mediated small intestine diseases with the potential to develop novel therapeutic agents. 4Thiazolidinones are important class of organosulfur compounds (Vicini et al., 2003), which predominantly have diverse pharmacologic activity (Lesyk et al., 2003). The 4-thiazolidinone heterocyclic framework is considered as a privileged structure, being a common moiety found in many biological active products and thus represents a very important pharmacophore (Mendgen et al., 2012). Thus, 4-thiazolidinones are reported to exhibit significant biological activities such as anticancer (Havrylyuk et al., 2009), antioxidant (Lozynskyi et al., 2015), anti-inflammatory (Vigorita et al., 2001; Charlier and Michaux, 2003), antimicrobial (Bonde et al., 2004). The purpose of our study was to evaluate novel 4-thiazolidinone derivatives (compounds Les-5054, Les5055 as dual COX/5-LOX inhibitors) as potential donors of $\mathrm{H}_{2} \mathrm{~S}$ generation and possible agents in therapy of small intestine injury. 


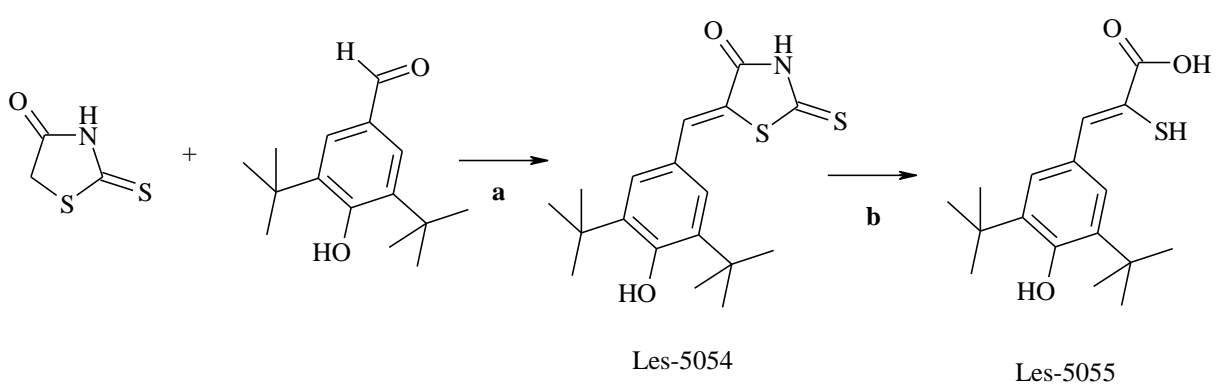

Scheme 1. Synthesis of Les-5054 and Les-5055. Reagents, conditions and yields: (a) AcONa, AcOH, reflux 1 h, $75 \%$; (b) NaOH $30 \%$ aq solution, reflux, 0.5 h; conc. $\mathrm{HCl}$ solution, $88 \%$.

\section{MATERIALS AND METHODS}

\section{Animals}

The experimental procedures were carried out in accordance with international guidelines for the use and care of laboratory animals, as well as the Committee on Bioethics of Lviv National Medical University (protocol No 3, from 16.03.2015). Male, outbred Wistar rats weighing 200-220 g were used. The rats were fed standard chow and water ad libitum, and were maintained under a constant $12 \mathrm{~h}$ light/dark cycle and an ambient temperature of $21-23^{\circ} \mathrm{C}$. Except for the last $24 \mathrm{~h}$ before the experiment, the animals were deprived of food, but had free access to water.

In rats, GI injury can be produced by water-immersion stress (WIS) described by Takagi et al. (1964) and is frequently employed as a model for the study of the mechanisms of stress on GI damage formation. Rats were placed in restraint cages and immersed vertically to the level of the xiphoid process in a water bath $\left(23^{\circ} \mathrm{C}\right)$ for $5 \mathrm{~h}$.

\section{Chemicals}

The compounds Les-5054 [5-(3,5-di-tert-butyl-4hydroxybenzylidene)-2-thioxothiazolidin-4-one] and Les-5055 [3(3,5-di-tert-butyl-4-hydroxyphenyl)-2-mercaptoacrylic acid] were synthesized by prof. Roman Lesyk in the Department of Pharmaceutical, Organic and Bioorganic Chemistry of Danylo Halytsky Lviv National Medical University (Scheme 1). In addition, already known dual COX/5-LOX inhibitor - 2A5DHT was used which was synthesized according to the method described previously (Sklyarov et al., 2011). The investigated compounds were administered intragastrically (via an orally introduced polyethylene tube) at a single dose $\left(10 \mathrm{mg} \cdot \mathrm{kg}^{-1}\right) 30 \mathrm{~min}$ prior to WIS. All test compounds were suspended in $1 \%$ carboxymethylcellulose with one drop of Twin- 80 solution.

\section{Study protocol}

The study used 4 groups of 8 animals each: 1 - intact animals were used as controls; 2 group - WIS during $5 \mathrm{~h}$ was used to induce GI damage; 3,4,5 groups were used to study the influence of compounds 2A5DHT, Les-5054, Les-5055 on the background of WIS. The rats were anesthetized with an intramuscular injection of ketamine $(60 \mathrm{mg} / \mathrm{kg})$. A trunk blood sample after decapitation was immediately collected into vials containing $0.1 \mathrm{~mL}$ of heparin. The small intestinal mucosa samples were collected and homogenized in saline (1:4), then centrifuged at $3000 \mathrm{rpm}$, supernatant was used to determine values of biochemical parameters.

\section{Biochemical assessment}

Lipid peroxidation levels were determined as malonic dialdehyde (MDA) concentration in homogenates of small intestinal mucosa, according to the procedure of Timirbulatov and Seleznev (1981), which measures concentrations of MDA in the range $50-500 \mu \mathrm{mol} / \mathrm{g}$. The content of NO in homogenate was determined as nitrites by the method of Green et al. (1982). The absorbance was read in a Stat fax at $550 \mathrm{~nm}$. NO concentration was expressed as $\mu \mathrm{mol} / \mathrm{g}$. Nitric oxide synthase (NOS) activity (total NOS, inducible NOS (iNOS), and constitutive NOS (cNOS) was measured by the method described by Ravaeva and Chuyan (2011) and was expressed in nmol $L$-citrylline/min $\times m g$ of protein. Arginase activity was determined by the method of Geyer and Dabich (1971) and was expressed in $\mu \mathrm{mol} / \mathrm{min} \cdot \mathrm{mg}$ of protein. The level of L-arginine in plasma samples was measured by Sakaguchi reaction (Alejnikova et al., 2000). Myeloperoxidase activity was measured according to the modified method of (Bradley et al., 1982). MPO activity in samples was expressed as units (U/mg). $\mathrm{H}_{2} \mathrm{~S}$ concentration in plasma samples was determined by reaction with $N, N$-dimethyl-para-phenylenediamine in the presence of $\mathrm{FeCl}_{3}$ and expressed as $\mu \mathrm{mol} / \mathrm{g} \times$ min (Olkhovskiy and Zaichko, 2013).

\section{Statistical analyses}

Each experiment was performed in triplicate and average values were recorded. Results are expressed as the means \pm SD. The data were evaluated statistically using Student's t-test. In general, a value of $\mathrm{p} \leq 0.05$ was regarded to be statistically significant and marked with asterisks $(* \mathrm{p} \leq 0.05)$.

\section{RESULTS AND DISCUSSION}

WIS markedly increased iNOS activity in the intestinal mucosa, the value reaching about 3 times $(\mathrm{P}<0.01)$ the basal level and being $188.9 \pm 9.8 \mathrm{nmol} / \mathrm{min} / \mathrm{mg}$ of protein. The administration of Les-5054 and Les-5055 on the background of WIS decreased the activity of iNOS for $21 \%(\mathrm{P}<0.01)$ and $19 \%$, respectively as 
compared with stress group. In contrast, activity of cNOS decreased more than 2 fold $(\mathrm{P}<0.01)$ in rats subjected to stress and increased in the animals treated with compounds Les-5054 and Les-5055 (48\% and $42 \%$ ( $\mathrm{P}<0.01)$, respectively). Studies showed that induction of iNOS in rats subjected to stress led to high nitrite anion $\left(\mathrm{NO}_{2}^{-}\right)$output conditions and enhanced more than 2 fold $(\mathrm{P}<0.01)$. Administration of compound Les-5054 reduced concentration of $\mathrm{NO}^{-}$for $27 \%(\mathrm{P}<0.05)$. After 5 hours of WIS, the $\mathrm{H}_{2} \mathrm{~S}$ concentration in plasma samples decreased for $30 \%$ $(\mathrm{P}<0.01)$. Pre-treatment with compound Les-5054 and compound Les-5055 prevented the reduction of $\mathrm{H}_{2} \mathrm{~S}$ level and increased it for $54 \%$ and $36 \%(\mathrm{P}<0.01)$ respectively. Concomitantly, both Larginine concentration in blood plasma and activity of arginase in intestinal mucosa decreased for $63 \%$ and $65 \% \quad(\mathrm{P}<0.01)$ respectively in rats subjected to WIS. Administration of compound Les-5055 didn't significantly change arginase activity while compound Les-5054 increased it in 2 fold $(\mathrm{P}<0.01)$ as compared with indices of WIS. Animals subjected to WIS were accompanied by increased concentration of end products of lipid peroxidation in small intestinal mucosa for $44 \%(\mathrm{P}<0.01)$ as compared to control group, indicating an intensification of oxidative processes. The content of malondialdehyde (MDA) decreased for $23 \%(\mathrm{P}<0.01)$ in Les-5054-pretreated rats subjected to WIS and $11 \%$ in animals treated with compound Les-5055 as compared with indices of stress group (Table 1). Superoxide dismutase (SOD) and catalase are the enzymes involved in protecting cells against free radical attack and oxidation. Stress during 5 hours slightly decreased SOD and catalase activity in small intestinal mucosa. However compound Les-5054 increased SOD activity for $48 \%$ $(\mathrm{P}<0.01)$ and compound Les-5055 for $29 \%(\mathrm{P}<0.01)$ as compared with stress group. Administration of compound Les-5054 increased catalase activity for $14 \%$. Indices of the catalase activity in Les-5055-pretreated rats subjected to WIS were similar to those of the group treated with compound Les-5054 + WIS. MPO activity, representing neutrophil infiltration in the mucosa, was shown to be markedly elevated in response to WIS, from $0.06 \pm$ 0.01 to $0,3 \pm 0,03 \mathrm{U} / \mathrm{mg}$ of protein $(\mathrm{P}<0.01)$. Treatment of the animals with compounds Les-5054 and Les-5055 decreased MPO activity in the intestinal mucosa by $60 \%(\mathrm{P}<0.01)$ and $30 \%$ $(\mathrm{P}<0.05)$ respectively compared with WIS group values (Table 2$)$. Dual COX/5-LOX inhibition with compound 2A5DHT decreased the activity of iNOS, MPO and NO content as compared to their activity in WIS group. Under this condition the content of MDA also decreased for $20 \%(\mathrm{P}<0.01)$. In our investigation it was established that parameters of NO-synthase system and intensity of lipid peroxidation processes on the background of compound Les5054 were practically the same like in compound 2A5DHT. However the activity of MPO and concentration of MDA decreased more significantly under conditions of the compound Les-5054 that may be linked with the concentration of $\mathrm{H}_{2} \mathrm{~S}$. Influence of oxidative stress induced by WIS produce ulcerative lesions in the stomach and didn't cause significant destructive changes in small intestinal mucosa as reported in previous studies (Fomenko et al., 2014). However development of stress during 5 hours was accompanied by the enhanced processes of lipoperoxidation and a fall in antioxidizing activities of small intestinal mucosa, increased content of NO and considerable activation of iNOS (Fomenko et al., 2015). Due to activation of NO-synthases, concentration of L-arginine, the substrate for NOS, in the plasma of blood decreased, that was showed in our previous findings of the stress influence to stomach and large intestine (Fomenko et al., 2015). Wallace and Wang (2015) showed that inhibition of $\mathrm{H}_{2} \mathrm{~S}$ synthesis in healthy rats led to gastrointestinal mucosal inflammation, reduced expression of cyclooxygenase and reduced synthesis of prostaglandins in the mucosa. The findings observed in the study by Fomenko et al. (2014) demonstrated a significant reduction in mean gastric lesions in rats supplemented with ATB-346 $\left(\mathrm{H}_{2} \mathrm{~S}\right.$ releasing NSAID), however, the parameters of lipoperoxidation and NO synthase activity did not differ substantially from naproxen treated group. COX inhibition with NSAIDs diverts arachidonate to the 5-LOX pathway thus increasing the formation of leukotrienes that can cause gastrointestinal ulceration. According to the ability of $\mathrm{H}_{2} \mathrm{~S}$ to reduce inflammation and protect tissues from injury, we decided to choose novel dual COX/5-LOX inhibitors as potential donors of $\mathrm{H}_{2} \mathrm{~S}$ and to explore it role in maintaining a balance between the destructive and the protective capacity of the small intestinal mucosa.

It is widely accepted that iNOS is calcium-independent and activated by inflammatory cytokines enzyme which produces relatively large amounts of NO under certain pathological conditions, contributes to mucosal injury and dysfunction (Lundberg and Weitzberg, 2012). Overproduction of NO in small intestinal mucosa may cause nitration of different compounds in tissues. Production of reactive oxygen species and NO in rats subjected to stress may form a cytotoxic metabolite - peroxynitrite which is capable of causing lipid peroxidation (Bhattacharyya et al., 2014). The present work showed a marked reduction in nitrite levels and iNOS activity in the treated group. This could be explained by the effects of $\mathrm{H}_{2} \mathrm{~S}$ to downregulate the expression of pro-inflammatory cytokines (interferon- $\gamma($ IFN $\gamma)$, tumour necrosis factor- $\alpha$ (TNF- $\alpha)$ ) (Wallace and Wang, 2015) which play a key role in activation of iNOS (Kolios et al., 2004). Thus, the new class of 4-thiazolidinone derivatives were shown to protect the GI mucosa against stress damage mainly due to release of $\mathrm{H}_{2} \mathrm{~S}$. The administration of tested compounds on the background of stress condition leads to normalization of arginase activity which is the endogenous inhibitor of iNOS, that uses the same substrate - Larginine.

The compound Les-5054 in this study increase $\mathrm{H}_{2} \mathrm{~S}$ level more as compared to compound Les-5055 and this could contribute to its faster resolution of inflammation. Accumulation of lipid peroxidation products (MDA) was inhibited by compound Les-5054 and decrease an intensification of oxidative processes in small intestine. Antioxidant system in normal condition scavenge reactive oxygen species (ROS), however in stress, ROS production overcomes the antioxidant system capacity and oxidative stress occurs, resulting in lipid peroxidation (Magierowski et al., 2015). 
Table 1: Effect of novel 4-thiazolidinones at the background of WIS on concentration of malonic dialdehyde, nitrite anion, activity of nitric oxide synthases and arginase in small intestinal mucosa and concentration of $\mathrm{H}_{2} \mathrm{~S}$ and $\mathrm{L}$-arginine in blood plasma.

\begin{tabular}{|c|c|c|c|c|c|}
\hline Experimental group & Control & WIS & 2A5DHT + WIS & Les-5054 + WIS & Les-5055 + WIS \\
\hline Variable & group & & 2ADDDT + WIS & Les-2004t the & \\
\hline Malonic dialdehyde $(\mu \mathrm{mol} / \mathrm{g})$ & $186.6 \pm 8.1$ & $268.4 \pm 30.7 * *$ & $215.7 \pm 10.9^{\# \prime}$ & $208.5 \pm 19.9^{\# \#}$ & $239.6 \pm 7.8$ \\
\hline Nitrite anion $(\mu \mathrm{mol} / \mathrm{g})$ & $1.2 \pm 0.1$ & $2.6 \pm 0.5 * *$ & $2.0 \pm 0.16^{\# \#}$ & $1.9 \pm 0.2^{\#}$ & $2.0 \pm 0.2^{\#}$ \\
\hline Inducible nitric oxide synthase - iNOS (nmol/min $\times \mathrm{mg}$ ) & $66.1 \pm 24.9$ & $188.9 \pm 9.8^{* *}$ & $144.7 \pm 24.7^{\#}$ & $148.9 \pm 6.7^{\# \#}$ & $153.5 \pm 32.0$ \\
\hline Constitutive nitric oxide synthase $-\mathrm{cNOS}(\mathrm{nmol} / \mathrm{min} \times \mathrm{mg})$ & $728.6 \pm 66.1$ & $312.5 \pm 32.3 * *$ & $455.12 \pm 66.0^{\#}$ & $462.6 \pm 30.4^{\mathrm{\# \#}}$ & $445.3 \pm 24.8^{\# \#}$ \\
\hline Arginase $(\mu \mathrm{mol} / \mathrm{min} \times \mathrm{mg})$ & $0.2 \pm 0.03$ & $0.07 \pm 0.01 * *$ & $0.15 \pm 0.02^{\# \#}$ & $0.14 \pm 0.07^{\# \#}$ & $0.09 \pm 0.01$ \\
\hline L-Arginine $(\mu \mathrm{mol} / \mathrm{l})$ & $46.7 \pm 3.6$ & $17.2 \pm 1.9^{* *}$ & $37.9 \pm 3.9^{\# \#}$ & $43.9 \pm 6.9^{\# \#}$ & $43.2 \pm 1.4^{\# \#}$ \\
\hline $\mathrm{H}_{2} \mathrm{~S}(\mu \mathrm{mol} / \mathrm{g} \times \min )$ & $88.4 \pm 2.7$ & $61.9 \pm 6.7 * *$ & $71.2 \pm 6.5^{\#}$ & $95.5 \pm 2.9^{\# \#}$ & $84.1 \pm 1.9^{\# \#}$ \\
\hline
\end{tabular}

Here and for table 2 results are expressed as mean \pm SD for 10 rats per group; ${ }^{*} \mathrm{p}<0.05,{ }^{* *} \mathrm{p}<0.01$ in comparison of control group; ${ }^{\#} \mathrm{p}<0.05,{ }^{\# \#} \mathrm{p}<0.01$ versus the indices of stress.

Table 2: The activity of myeloperoxidase and antioxidant enzymes in small intestinal mucosa of rats.

\begin{tabular}{|c|c|c|c|c|c|}
\hline $\begin{array}{c}\text { Experimental group } \\
\text { Variable }\end{array}$ & Control group & WIS & 2A5DHT + WIS & Les-5054 + WIS & Les-5055 + WIS \\
\hline $\mathrm{SOD},(\mathrm{U} / \mathrm{mg})$ & $23.9 \pm 1.0$ & $20.2 \pm 1.8^{*}$ & $27.5 \pm 0.1^{\# \#}$ & $30.0 \pm 0.8^{\# \#}$ & $26.1 \pm 2.7^{\# \#}$ \\
\hline $\mathrm{CAT},\left(\mu \mathrm{mol} \mathrm{H}_{2} \mathrm{O}_{2} / \min \times \mathrm{mg}\right)$ & $16.9 \pm 1.6$ & $15.7 \pm 2.9$ & $18.6 \pm 2.4$ & $17.9 \pm 1.6$ & $17.5 \pm 2.3$ \\
\hline MPO $(\mathrm{U} / \mathrm{mg})$ & $0.06 \pm 0.01$ & $0.3 \pm 0.03 * *$ & $0.14 \pm 0.05^{\# \#}$ & $0.12 \pm 0.01^{\# \#}$ & $0.21 \pm 0.05^{\#}$ \\
\hline
\end{tabular}

Observation that administration of 4-thiazolidinone derivatives, particularly compound Les-5054, increase antioxidant enzyme activities in response to stress suggested that 4thiazolidinone derivatives as a novel $\mathrm{H}_{2} \mathrm{~S}$ donors inhibits oxidative damage of tissue, in part through scavenging of oxygen-derived free radicals. MPO is an enzyme found in neutrophil and has been used as an biochemical marker for granulocyte infiltration into various tissues, including the gastrointestinal tract. The key role of MPO is production of hypochlorous acid from hydrogen peroxide and chloride anion. In the present study, we found that stress condition resulted in higher activity of this enzyme compared to control group. As a result hypochlorous acid reacts with other biological molecules to generate secondary oxidation products, which increase oxidative damage (Pálinkás et al., 2015). It was found the administration of novel 4-thiazolidinone derivatives, as $\mathrm{H}_{2} \mathrm{~S}$ releasing compounds can inhibit peroxidase activity of MPO, particularly compound Les-5054.

\section{CONCLUSION}

From the above context, administration of novel 4thiazolidinone derivatives demonstrated a remarkable anti inflammatory and cytoprotective ability against experimentally induced GI damages by the reduction of inflammatory markers, prevented oxidative damage leading to regeneration of cells. These studies suggest important role for 4-thiazolidinone derivatives (particularly compound Les-5054) as a novel $\mathrm{H}_{2} \mathrm{~S}$ donor in regulating inflammatory processes, particularly in gastrointestinal tract and these properties can be exploited in the design of novel therapies for inflammatory diseases.

\section{Addendum}

Synthesis of 5-(3,5-di-tert-butyl-4-hydroxybenzylidene)2-thioxothiazolidin-4-one (Les-5054) and 3-(3,5-di-tert-butyl-4hydroxyphenyl)-2-mercaptoacrylic acid (Les-5055) was performed according to methods described previously (Unangst et al., 1994; Kaminskyy et al., 2012). All materials were purchased from commercial sources and used without purification. Melting points were measured in open capillary tubes and were uncorrected. The elemental analyses $(\mathrm{C}, \mathrm{H}, \mathrm{N})$ were performed using the Perkin-Elmer $2400 \mathrm{CHN}$ analyzer and were within $0.4 \%$ of the theoretical values. The ${ }^{1} \mathrm{H}$ NMR spectra were recorded on Varian Gemini $400 \mathrm{MHz}$ or Bruker $125 \mathrm{MHz}$ for frequencies $100 \mathrm{MHz}$ in DMSO- $d 6$ using tetramethylsilane as an internal standard. Chemical shifts are reported in ppm units with use of $\delta$ scale. The purity of all obtained compounds was checked by TLC.

General procedure for the synthesis of 5-(3,5-di-tert-butyl-4hydroxybenzylidene)-2-thioxothiazolidin-4-one (Les-5054).

A mixture of 2-thioxo-thiazolidin-4-one $(10 \mathrm{mmol})$ and 3,5-di-tert-butyl-4-hydroxy-benzaldehyde $(11 \mathrm{mmol})$ was refluxed for $1 \mathrm{~h}$ in glacial acetic acid $(10 \mathrm{~mL})$ in the presence of a catalytic amount of fused sodium acetate, then left overnight at room temperature. The precipitated crystals were filtered off, washed with methanol $(5-10 \mathrm{~mL})$, and recrystallized from acetic acid (10$15 \mathrm{~mL}$ )

5-(3,5-Di-tert-butyl-4-hydroxybenzylidene)-2-thioxothiazolidin-4one (Les-5054)

1H NMR (400 MHz, DMSO-d $\left.\mathrm{d}_{6}\right): \delta 1.41(\mathrm{~s}, 18 \mathrm{H}, t-B u)$, 7.39 (s, 2H, arom.), $7.65(\mathrm{~s}, 1 \mathrm{H}, \mathrm{CH}), 7.69(\mathrm{~s}, 1 \mathrm{H}, \mathrm{OH}), 9.58(\mathrm{~s}$, $1 \mathrm{H}, \mathrm{NH}$ ). Anal.Calcd for $\mathrm{C}_{18} \mathrm{H}_{23} \mathrm{NO}_{2} \mathrm{~S}_{2}: \mathrm{C}, 61.86 ; \mathrm{H}, 6.63 ; \mathrm{N}, 4.01$. Found: $\mathrm{C}, 61.87 ; \mathrm{H}, 6.61 ; \mathrm{N}, 4.03$.

General procedure for the synthesis of 3-(3,5-di-tert-butyl-4hydroxyphenyl)-2-mercaptoacrylic acid (Les-5055)

A $30 \%$ aq solution of $\mathrm{NaOH}(50 \mathrm{mmol})$ was added to 5 -(3,5-di-tert-butyl-4-hydroxybenzylidene)-2-thioxothiazolidin-4one $(10 \mathrm{mmol})$. The reaction mixture was refluxed for $30 \mathrm{~min}$ and cooled. An equimolar amount of conc. $\mathrm{HCl}$ was added and the mixture was diluted with $\mathrm{H}_{2} \mathrm{O}(150 \mathrm{ml})$. The product was filtered and recrystallized from ethanol. 
3-(3,5-di-tert-butyl-4-hydroxyphenyl)-2-mercaptoacrylic acid (Les-5055) Yield $88 \%, \mathrm{mp} 170-172^{\circ} \mathrm{C}(\mathrm{EtOH})$.

1H NMR (400 MHz, DMSO-d $\left.)_{6}\right): \delta 1.40(\mathrm{~s}, 18 \mathrm{H}, t-B u)$, 5.17 (s, 1H, CH), 7.35 (s, 2H, arom.), 7.62 (s, 1H, OH), 7.88 (s, $1 \mathrm{H}, \mathrm{SH}$ ), 13.72 (brs, $1 \mathrm{H}, \mathrm{COOH})$. Anal.Calcd for $\mathrm{C}_{17} \mathrm{H}_{24} \mathrm{O}_{3} \mathrm{~S}: \mathrm{C}$, 66.20; H, 7.84. Found: C, 66.22; H, 7.83.

\section{Financial support and sponsorship: Nil.}

Conflict of Interests: There are no conflicts of interest.

\section{REFERENCES}

Aboubakr EM, Taye A, El-Moselhy MA, Hassan MK. Protective effect of hydrogen sulfide against cold restraint stress-induced gastric mucosal injury in rats. Arch Pharm Res, 2013; 36:1507-1515.

Alejnikova TL, Rubtsova GV., Pavlova NA. 2000. Manuals for practical lessons in biochemistry. M.: Medicine.

Bhattacharyya A, Chattopadhyay R, Mitra S, Crowe SE. Oxidative stress: an essential factor in the pathogenesis of gastrointestinal mucosal diseases. Physiol Rev, 2014; 94:329-354.

Bonde CG, Gaikwad NJ. Synthesis and preliminary evaluation of some pyrazine containing thiazolines and thiazolidinones as antimicrobial agents. Bioorg Med Chem, 2004; 12:2151-2161.

Bradley PP, Priebat DA, Christensen RD, Rothstein G. Measurement of cutaneous inflammation: estimation of neutrophil content with an enzyme marker. J. Invest. Dermatol, 1982; 78:206-209.

Charlier C, Michaux C. Dual inhibition of cyclooxygenase-2 (COX2) and 5-lipoxygenase (5-LOX) as a new strategy to provide safer non-steroidal anti-inflammatory drugs. Eur J Med Chem, 2003; 38:645-659.

Chan MV, Wallace JL. Hydrogen sulfide-based therapeutics and gastrointestinal diseases: translating physiology to treatments. Am J Physiol Gastrointest Liver Physiol, 2013; 305:G467-G473.

Fomenko I, Bondarchuk T, Emelyanenko V, Denysenko N, Pavlo S, Ilkiv I, Sklyarov A. Changes of nitric oxide system and lipid peroxidation parameters in the digestive system of rats under conditions of acute stress, and use of nonsteroidal anti-inflammatory drugs. Curr Issues Pharm Med Sci, 2015; 28:37-41.

Fomenko IS, Korniychuk OP, Hural AR, Shykula RG, Ilkiv II, Sklyarov AY. Role of cyclooxygenase in modification of intestinal microflora under stress condition. Fiziolohichnyi zhurnal, 2015; 61:42-49.

Fomenko I, Sklyarov A, Bondarchuk T, Biletska L, Panasyuk N, Wallace JL. Effects of conventional and hydrogen sulfide-releasing nonsteroidal anti-inflammatory drugs in rats with stress-induced and epinephrineinduced gastric damage. Stress, 2014; 17:528-537.

Geyer JW, Dabich D. Rapid method for determination of arginase activity in tissue homogenates. Anal Biochem, 1971; 39:412-417

Green LC, Wagner DA, Glogowski J, Skipper PL, Wishnok JS, Tannenbaum SR. Analysis of nitrate, nitrite, and $\left[{ }^{15} \mathrm{~N}\right]$ nitrate in biological fluids. Anal Biochem, 1982; 126:131-138.

Havrylyuk D, Zimenkovsky B, Vasylenko O, Zaprutko L, Gzella A, Lesyk R. Synthesis of novel thiazolone-based compounds containing pyrazoline moiety and evaluation of their anticancer activity. Eur J Med Chem, 2009; 44:1396-1404.

Kaminskyy D, Khyluk D, Vasylenko O, Lesyk R. An efficient method for the transformation of 5-ylidenerhodanines into 2,3,5-trisubstituted4-thiazolidinones. Tetrahedron Lett, 2012; 53:557-559.

Kolios G, Valatas V, Ward SG. Nitric oxide in inflammatory bowel disease: a universal messenger in an unsolved puzzle. Immunology, 2004; 113:427-437.

Lambert GP. Stress-induced gastrointestinal barrier dysfunction and its inflammatory effects. J. Anim Sci, 2009; 87:101-108.

Lesyk RB, Zimenkovsky BS. 4-Thiazolidones: centenarian history, current status and perspectives for modern organic and medicinal chemistry. Curr Org Chem, 2004; 8:1547-1577.

Lou LX, Geng B, Du JB, Tang CS. Hydrogen sulphide-induced hypothermia attenuates stress-related ulceration in rats. Clin Exp Pharmacol Physiol, 2008; 35:223-228.

Lozynskyi AV, Kaminskyy DV, Romanchyshyn KB, Semenciv NG, Ogurtsov VV, Nektegayev IO, Lesyk RB. Screening of antioxidant and anti-inflammatory activities among thiopyrano[2,3-d]thiazoles. Biopolym Cell, 2015; 31:131-137.

Lundberg JO, Weitzberg E. Biology of nitrogen oxides in the gastrointestinal tract. Gut, 2012; 62:616-629.

Magierowski M, Magierowska K, Kwiecien S, Brzozowski T. Gaseous Mediators Nitric Oxide and Hydrogen Sulfide in the Mechanism of Gastrointestinal Integrity, Protection and Ulcer Healing. Molecules, 2015; 20:9099-9123.

Mendgen T, Steuer C, Klein CD. Privileged scaffolds or promiscuous binders: a comparative study on rhodanines and related heterocycles in medicinal chemistry. J Med Chem, 2012; 55:743-753.

Olkhovskiy OS, Zaichko NV. Influence propargyl glycine and sodium content of hydrogen and $\mathrm{H}_{2} \mathrm{~S}$-indices of antioxidant system in the myocardium of rats of different ages. Medical Chemistry, 2013; 15:10-15.

Pálinkás Z, Furtmüller PG, Nagy A, Jakopitsch C, Pirker KF, Magierowski M, Jasnos K, Wallace JL, Obinger C, Nagy P. Interactions of hydrogen sulfide with myeloperoxidase. Br J Pharmacol, 2015; 172:1516-1532.

Ravaeva MY, Chuyan EN. Changes in the synthesis of nitric oxide system activity under the influence of low-intensity millimeter radiation. Uchenye zapiski Tavricheskogo natsional'nogo Universiteta im VI Vernadskogo Seriya: Biologiya, Himiya, 2011; 24:201-210.

Sklyarov AY, Lesyk RB, Panasyuk NB, Fomenko IS, Havrylyuk DY. Comparison of dual acting drugs and conventional NSAIDs towards parameters of NO-synthase system and oxidative stress in mucosal membrane of large intestine of rats with experimental ulcerative colitis. Biopolym Cell, 2011;27:147-153.

Takagi K, Kasuya Y, Watanabe K. Studies on the drugs for peptic ulcer. A reliable method for producing stress ulcer in rats. Chem Pharm Bull. $1964 ; 12: 465-472$.

Timirbulatov MA, Seleznev EI. Method for increasing the intensity of free radical oxidation of lipid-containing components of the blood and its diagnostic significance. Lab. Delo, 1981; 4:209-211.

Vicini P, Geronikaki A, Incerti M, Busonera B, Poni G, Cabras C. A, La Colla P. Synthesis and biological evaluation of benzo[ $d]$ isothiazole, benzothiazole and thiazole Schiff bases. Bioorg Med Chem, 2003; 11:47854789 .

Vigorita MG, Ottana R, Monforte F, Maccari R, Trovato A, Monforte MT, Taviano MF. Synthesis and antiinflammatory, analgesic activity of 3,3'-(1,2-Ethanediyl)-bis[2-aryl-4-thiazolidinone] chiral compounds. Part 10. Bioorg Med Chem Lett, 2001; 11:2791-2794.

Wallace JL. Physiological and pathophysiological roles of hydrogen sulfide in the gastrointestinal tract. Antioxid Redox Signal, 2010; 12:11251133 .

Wallace JL, Wang R. Hydrogen sulfide-based therapeutics: exploiting a unique but ubiquitous gasotransmitter. Nature Reviews Drug Discovery, 2015; 14:329-345.

Zayachkivska O, Havryluk O, Hrycevych N, Bula N, Grushka O, Wallace JL. Cytoprotective effects of hydrogen sulfide in novel rat models of non-erosive esophagitis. PloS ONE, 2014; 9:e110688.

Unangst PC, Connor DT, Cetenko WA, Sorenson RJ, Kostlan CR, Sircar JC, Wright CD, Schrier DJ, Dyer RD. Synthesis and biological evaluation of 5-[[3,5-bis(1,1-dimethylethyl)-4-hydroxyphenyl] methylene] oxazoles,-thiazoles, and-imidazoles: novel dual 5-lipoxygenase and cyclooxygenase inhibitors with antiinflammatory activity. J Med Chem, 1994;37:322-328.

\section{How to cite this article:}

Ilkiv I, Lesyk R, Sklyarov O. Evaluation of Novel 4Thiazolidinone-Based Derivatives as Possible Cytoprotective Agents Against Stress Model In Rats. J App Pharm Sci, 2017; 7 (01): 199-203. 